\title{
The Concept of Urban Green Open Space Development with Green Infrastructure in Kendari City
}

\author{
$1^{\text {st }}$ Irma Nurjannah ${ }^{1}, 2^{\text {nd }}$ Dwi Rinasuri Nuroduola ${ }^{2}, 3^{\text {rd }}$ I Made Krisna Adhi Dahrma ${ }^{3}, 4^{\text {th }}$ \\ Weko Indira Romanti Aulia ${ }^{4}$ \\ \{nurjannah.irma@gmail.com¹, mailto_drnuroduola@yahoo.com², \\ krz.vista@gmail.com ${ }^{3}$ \}
}

Department of Architecture, Faculty of Engineering, Halu Oleo University, Indonesia ${ }^{1}$

\begin{abstract}
Green open space (GOS) is essential in a city development as it improves the quality of urban ecology. Therefore, the GOS needs to be considered and managed. The GOS in Kendari City is widely available but it is dependent on population growth and city development. However, the arrangement and development of green open space in Kendari City do not yet have a development concept, which indicates that the GOS is merely a complementary and not a priority in city development. This research aimed to find out the implementation of the Kendari City green open space development concept with the green infrastructure approach. This study used a quantitative method to obtain the general conditions and Kendari City green open space developments and integrate the application of the green infrastructure concept to the development of spatial plans along with the development of the green open space. The results show that the concept of green infrastructure in Kendari City green open space can be implemented through the structural green space arrangement model, namely the ecological, corridor, and matrix patterns.
\end{abstract}

Keywords: Green Infrastructure, Green open space, Kendari City

\section{Introduction}

The establishment of green open space (GOS) in urban areas aims to improve the quality of the urban environment that is comfortable, fresh, beautiful, and clean. It is also an urban environment facility that can create harmony between the natural and built environments that are useful for the community as well as creating a liveable, habitable, and sustainable city. Green open space also brings many benefits, such as functioning as a water storage and hot/humid tropical climate regulator, evacuation room facilities for emergencies, research, education, or counseling site, and regional identity exhibition. It also improves the pride and prestige of the region as well as increase the economic value of urban land.

The development of Kendari City needs to be controlled particularly regarding the rapid population growth and increasing development. In controlling these developments, Kendari City refers to the guidelines of the 2017-2037 Regional Spatial Plan. The GOS area of Kendari in 2018 is $165,516,709 \mathrm{~m}^{2}$ or $54.59 \%$ of the total Kendari City area. The development of green open space is currently dominated by urban parks and sports facilities. The concept of GOS development in Kendari City needs to consider other determinants, such as the development of city transportation networks where Kendari City has commuter line transportation modes in the 
form of Translulo and future development plans in the form of providing railway lines. The ecological open space that functions as a water catchment area and the lungs of the city needs to be maintained and arranged accordingly by determining the direction of development through clear concepts, such as forest areas, city parks, the green lanes on the left and right sides of rivers, as well as a green mangrove area in the bay that also functions as a green corridor.

The development of Kendari City is characterized by the population growth, dense buildings, increasing number of vehicles, and the higher number of road lanes and new types of land transportation such as the planned railway line. This will trigger an increase in pollution and city warming in the form of an urban heat island. Therefore, the green open space (GOS) needs to have a clear development concept so that the ecological benefits of the quality GOS can reduce pollution and its effects on urban warming.

\section{Literature Review}

Green Infrastructure is the interconnection of natural and open spaces networks that preserve the value and function of natural ecosystems, maintain clean air and water, and provide a number of benefits for humans and other living things (Benedict and McMahon, 2006 in R. Young et al. 2014). Green infrastructure can also be interpreted as a number of products, technologies, and practices that use natural or artificial systems that mimic natural processes to encourage environmental quality while providing infrastructure and services (USEPA, 2013b in R. Young, et al, 2014). NSF Auckland Workshop (2012) in R. Young, et al (2014) defines green infrastructure as a natural and artificial ecological system that is integrated with the artificial environment to provide the widest possible service for ecosystems, communities, and infrastructure.

What is essential in the notion of green infrastructure is that it includes not only natural systems but also artificial systems or technology, which mimic or utilize natural systems to benefit humans and other living creatures as well as maintain environmental sustainability.

Green open space (GOS) as a form of green infrastructure is part of the city's infrastructure network. Green infrastructure is a popular framework in the context of environmental preservation (Wickham et al., 2010). One essential aspect of green infrastructure is identifying ecological networks (Lewis, 1964; Noss and Haris, 1986; Hoctor et al., 2000; Benedict and McMahon, 2002; Carr et al., 2002; Weber, 2004; Weber et al. ., 2006; Hoctor et al., 2008 in Wickhman, 2010). The main components of the ecosystem network are (Wickham et al., 2010):

1. Hubs, which are large areas of natural plants.

2. Links, which are linear-shaped areas which are mainly formed by river networks that connect hubs

Green infrastructure is made to meet engineering criteria while satisfying ecological criteria. Thus, it can also be called ecological infrastructure, which consists of (Bohemen, 2002):

1. Natural core area, which functions to preserve and manage ecosystems, habitats, and species populations.

2. Nature development area, which is the corridor or connection in the form of straight landscape elements, wide zones or large areas designed to be multifunctional zones and transitional zones.

3. Buffer zones, which protect the core area network from negative influences. 


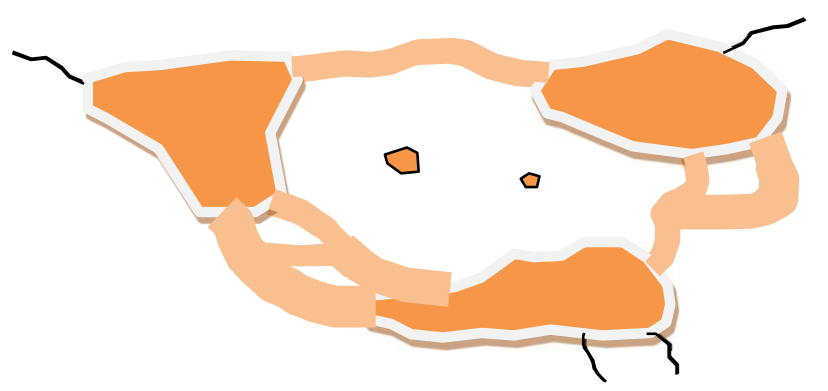

Figure 1. Structure of an ecological infrastructure. Source: Yuan and Ru, 2011

Other structures of the ecological infrastructure are (Weber et al., 2008; Mell, 2009 and Lockhart, 2009 in Yuan and $\mathrm{Ru}, 2011$ ):

1. Ecological path, which is part of the features of ecological land with large size, beneficial continuity, and important ecological functions, such as natural forests, wetlands, city parks, large green land, and others)

2. Corridor (usually distributed linearly and different from the landscape on both sides). Natural corridors range from $30 \mathrm{~m}$ to $120 \mathrm{~m}$.

3. Matrix (ecological point for the migration of animals or other people when the ecological path or corridor cannot be connected).

The pattern of road networks and green open space will determine the spatial structure of a city. Access provided by the road network can determine the location of activity patterns, which can affect green space patterns (Bolt, 1983 in Schrijnen, 2002). From several road network patterns such as in Figure 2, a fairly wide grid or circular patterns can provide space for GOS, which can function as a mold for urban activity patterns (Schrijnen, 2002). Placing urban activity centers in the middle and placing infrastructure in open landscapes between cities or villages tends to place green open space as a recreation element or a green area in a vulnerable position, because cities tend to develop out of town, while putting green functions in the center of activity and placing infrastructure within urban areas as a center of activity and built-up areas will further enable arrangements that are far more attractive especially for green open space (Schrijnen, 2002).

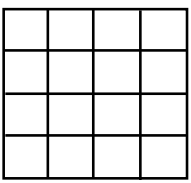

Grid

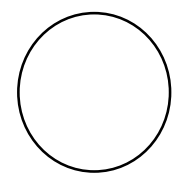

Circular

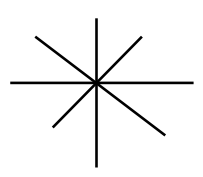

Radial

Figure 2. Patterns of the road network. Source: Schrijnen, 2002 


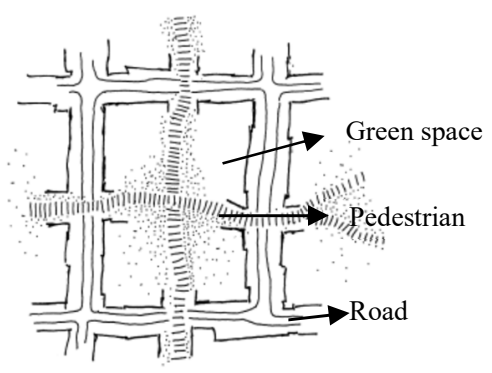

Figure 3. The pattern of red and green infrastructure. Source: Schrijnen, 2002

There are several principles for designing green open space as city infrastructure, namely:

1. Integration of green-gray areas - combining green and gray infrastructure. Green infrastructure planning is carried out by integrating and coordinating urban green spaces with other infrastructure, such as transportation and utility systems.

2. Connectivity - creating a network of green spaces. Green infrastructure planning must consider green infrastructure with interconnected structures and functions.

3. Multifunctionality - providing and improving various functions and services. Green infrastructure planning aims to combine various functions to increase the capacity of urban green spaces to provide many benefits - creating synergies while reducing conflicts and trade-offs.

4. Social inclusion - collaborative and participatory planning. Green infrastructure planning aims at collaborative and socially inclusive processes. In this case, the planning process is open to all and combines the knowledge and needs of various parties.

\section{Research Method}

This study used a mixed method between qualitative and quantitative methods with a comparative approach. Qualitatively, a survey was conducted on the condition and extent of urban green open space in Kendari City per subdistrict. Extensive green open space data from related agencies were collected and the latest hamlets and neighborhoods of Kendari City were reviewed. Quantitative analysis method was used to find out the general conditions and development of green open space in Kendari City. The application of the green infrastructure concept to the development of spatial plans was integrated qualitatively along with the development of the green open space conditions.

\section{Results and Discussion}

The total area of green open space in Kendari City reaches $165,516,709 \mathrm{~m}^{2}$ or $54.59 \%$ of the Kendari City total area. This means that the overall green open space in Kendari City can be considered as adequate because it is more than the minimum requirement of $30 \%$ as regulated. However, if the availability of green open space was considered based on the size of the subdistrict, there were several subdistricts where the availability of open green space was lower than $30 \%$, such as in West Kendari sub-district ( $8 \%$ ) or Kadia subdistrict (29.05\%). In addition, there were several subdistricts where the availability of green space needs to be maintained, 
such as in Kendari subdistrict (32.89\%), Poasia subdistrict (44.34\%), and Wua-Wua subdistrict $(48.90 \%)$, because their GOS availability was close to the required minimum limit.

Table 1. Area of green open space and total area per subdistrict in Kendari City

\begin{tabular}{|c|c|c|c|c|}
\hline \multirow{2}{*}{ Subdistrict } & \multicolumn{2}{|c|}{ Area } & \multirow{2}{*}{ Existing GOS area $\left(\mathbf{m}^{2}\right)$} & \multirow{2}{*}{$\begin{array}{c}\text { Existing GOS } \\
\text { percentage (\%) }\end{array}$} \\
\hline & (Ha) & $\left(\mathbf{m}^{2}\right)$ & & \\
\hline Baruga & $4,727.33$ & $47,273,278$ & $40,157,565$ & 84.95 \\
\hline Poasia & $4,119.98$ & $41,199,793$ & $18,269,653$ & 44.34 \\
\hline Kambu & $2,152.94$ & $21,529,431$ & $13,773,904$ & 63.98 \\
\hline Wua-wua & $1,129.19$ & $11,291,926$ & $5,521,788$ & 48.90 \\
\hline Kadia & 715.50 & $7,155,042$ & $2,078,349$ & 29.05 \\
\hline Kendari & $1,595.18$ & $15,951,844$ & $5,246,154$ & 32.89 \\
\hline Puuwatu & $4,280.73$ & $42,807,268$ & $36,438,002$ & 85.12 \\
\hline Mandoga & $2,021.89$ & $20,218,885$ & $10,428,809$ & 51.58 \\
\hline West Kendari & $1,982.98$ & $19,829,840$ & $1,782,841$ & 8.99 \\
\hline Nambo & $2,547.12$ & $25,471,157$ & $21,490,055$ & 84.37 \\
\hline Abeli & $1,558.67$ & $15,586,670$ & $10,329,589$ & 66.27 \\
\hline Total & & $268,315,134$ & $165,516,709$ & 54.59 \\
\hline
\end{tabular}

Source: GOS analysis of Kendari City, 2018

The survey results show that Kendari City has urban natural green open space of $10,149,994 \mathrm{Ha}$ or $101,499,904 \mathrm{~m}^{2}(31.76 \%)$ and non-natural green open space of $6,408,6005$ Ha or $64,086,005 \mathrm{~m}^{2}(22.83 \%)$ of the total area Kendari City. Baruga Subdistrict has the highest natural green open space with the area of 3,497.3811 Ha or 34,973,811 $\mathrm{m} 2$ (73.98\%). This high percentage is due to the urban forests in the Baruga subdistrict. Meanwhile, the smallest urban natural green open space is in West Kendari subdistrict as it is dominated by densely populated areas that even occupies a protected forest area that functions as an ecological buffer. The largest areas of non-natural GOS (the built environment) are in Kambu subdistrict (45.27\%), Mandonga subdistrict (33.29\%), and Puuwatu subdistrict (32.02\%).

In Law No. 26 of 2007 concerning Spatial Planning and described later in Ministerial Regulation Number 5 of 2008 , the minimum availability of urban green space is $30 \%$ of the area both in the city and in each subdistrict. As can be seen in Table 2, the smallest green open space at the sub-district level is in West Kendari subdistrict with a percentage of 9\% $(5,948,952 \mathrm{~m} 2)$ from its area of $19,829,840 \mathrm{~m} 2$. To reach the $30 \%$ standard, the subdistrict needs addition of $4,166,111 \mathrm{~m} 2$ land for GOS. The other subdistrict that has GOS area lower than $30 \%$ of its total area is Kadia Subdistrict. It has a total area of 7,155,042 $\mathrm{m} 2$ but only 2,078,349 $\mathrm{m} 2(29 \%)$ for GOS. It still needs addition of $68,164 \mathrm{~m} 2$ to reach the $30 \%$ standard of GOS area. Other subdistricts already have green open space above $30 \%$.

Table 2. Area required by each district to reach the $30 \%$ standard

\begin{tabular}{|c|c|c|c|c|c|}
\hline \multirow[b]{2}{*}{ Subdistrict } & \multicolumn{2}{|c|}{ Area } & \multirow{2}{*}{$\begin{array}{l}\text { Existing GOS } \\
\text { area }\left(\mathbf{m}^{2}\right)\end{array}$} & \multirow{2}{*}{$\begin{array}{c}\text { Existing GOS } \\
\text { percentage (\%) }\end{array}$} & \multirow{2}{*}{$\begin{array}{c}\text { The required } \\
30 \% \text { area for } \\
\text { GOS (m2) }\end{array}$} \\
\hline & (Ha) & (m2) & & & \\
\hline Baruga & 4,727 & $47,273,278$ & $40,157,565$ & 85 & $14,181,983$ \\
\hline Poasia & 4,120 & $41,199,793$ & $18,269,653$ & 44 & $12,359,938$ \\
\hline Kambu & 2,153 & $21,529,431$ & $13,773,904$ & 64 & $6,458,829$ \\
\hline Wua-wua & 1,129 & $11,291,926$ & $5,521,788$ & 49 & $3,387,578$ \\
\hline Kadia & 716 & $7,155,042$ & $2,078,349$ & 29 & $2,146,513$ \\
\hline Kendari & 1,595 & $15,951,844$ & $5,246,154$ & 33 & $4,785,553$ \\
\hline Puuwatu & 4,281 & $42,807,268$ & $36,438,002$ & 85 & $12,842,180$ \\
\hline
\end{tabular}




\begin{tabular}{lccccc} 
Mandoga & 2,022 & $20,218,885$ & $10,428,809$ & 52 & $6,065,666$ \\
West Kendari & 1,983 & $19,829,840$ & $1,782,841$ & 9 & $5,948,952$ \\
Nambo & 2,547 & $25,471,157$ & $21,490,055$ & 84 & $7,641,347$ \\
Abeli & 1,559 & $15,586,670$ & $10,329,589$ & 66 & $4,676,001$ \\
Total & & $\mathbf{2 6 8 , 3 1 5 , 1 3 4}$ & $\mathbf{1 6 5 , 5 1 6 , 7 0 9}$ & $\mathbf{5 5}$ & \\
\hline
\end{tabular}

Source: GOS analysis of Kendari City, 2018

\subsection{Development of Green Open Space in Kendari City with the Green Infrastructure Concept \\ 4.1.1 Ecological Path}

Natural green open space that surrounds Kendari City are production forests, mixed gardens, and protection forests, which also function as ecological paths. The ecological path will naturally or ecologically function in maintaining natural functions such as biodiversity, water cycle, conservation of groundwater for the supply of clean water, flood control, oxygen cycles, microclimate modifiers, and food sources. In a city structure, this ecological path functions as a green belt that limits the development of the city towards the outskirts and the countryside (urban sprawl). Hence, the green belt needs to be legally protected through regional regulations which explicitly give directions regarding the green belt territorial boundary, the direction of its use, and strict sanctions for those who violate the green belt utilization as regulated in the regional regulation.

Moreover, wetlands and mangroves which are found in the coastal areas of Kendari City also function as ecological paths. Naturally, the wetlands and mangroves function as biodiversity in the city center, flood and rob control, microclimate modifier, food source, and recreation sites. The potential for developing this natural function into an ecological engineering function such as a waste treatment facility with constructed wetland methods needs to be considered in the future. In addition, ecological paths of wetlands and mangroves in a city structure will function as a green belt that limits the development of the city towards the sea. Thus, it can prevent reclamation that can damage coastal and marine natural ecosystems. However, the Kendari City coastal area has a strategic value that is not only as a recreation site but it also functions as transportation, logistics, and industral facilities. Therefore, the protection of wetlands and mangroves by regional regulations should also determine the utilization zone of the Kendari City coastal area related to their strategic values.

\subsubsection{Corridor}

Corridor structure should be formed ecologically and spatially. Rivers that divide Kendari City function as ecological corridors. Green open space can be developed and maintained in the river border area and buffer zone which is located as an intermediary area between the river and commensurate river areas with the built area. In this ecological corridor, technology for sustainable drainage can be applied as recommended in the 2016 - 2020 Drainage Master Plan for Kendari City. The ecological corridor dimension follows the width of the river border based on the provisions of Ministerial Regulation No. 05/PRT/M/2008, added to the width of the buffer zone to reach the recommended dimensions of $30 \mathrm{~m}-120 \mathrm{~m}$ on the right and left sides of the river. 
Table 3. The dimension of ecological GOS as corridors in Kendari City

\begin{tabular}{|c|c|c|c|c|}
\hline No & River name & Length (Km) & Flow (litre/s) & $\begin{array}{l}\text { Corridor width } \\
\text { (m) }\end{array}$ \\
\hline 1. & Wanggu & $\overline{c 17.0}$ & 7,487 & 120 \\
\hline 2. & Lasolo & 6.52 & 0.22 & 50 \\
\hline 3. & Kampung Salo & 4.70 & 0.23 & 50 \\
\hline 4. & Mandonga & 7.90 & 0.214 & 50 \\
\hline 5. & Kambu & 15.01 & & 30 \\
\hline 6. & Kadia & 10.39 & & 30 \\
\hline 7. & Abeli & 10.10 & & 30 \\
\hline 8. & Abeli Dalam & 6.55 & & 30 \\
\hline 9. & Amarilis & 2.30 & 0.17 & 50 \\
\hline 10. & Lepo-Lepo & 8.91 & & 30 \\
\hline 11. & Watu-Watu & 2.33 & 0.35 & 70 \\
\hline 12. & Nanga-Nanga/Andonohu & 5.54 & & 30 \\
\hline 13. & Mokoau & 6.43 & & 30 \\
\hline 14. & Lahundape & 4.68 & 0.46 & 70 \\
\hline 15. & Punggaloba & 4.01 & 0.24 & 50 \\
\hline 16. & Lemo & 4.21 & & 30 \\
\hline 17. & Lalonggori & 4.41 & & 30 \\
\hline 18. & Mata & 2.60 & 0.08 & 50 \\
\hline 19. & Watubangga & 3.41 & & 30 \\
\hline 20. & Wua-Wua & 4.76 & & 30 \\
\hline 21. & Benu-Benua & 2.91 & 0.43 & 70 \\
\hline \multirow[t]{2}{*}{22.} & Korumba & 5.56 & & 30 \\
\hline & Total & 144.64 & $7,489.394$ & \\
\hline
\end{tabular}

Source: Statistics of Kendari City (2018) and Analysis (2018)

The spatial corridor is formed from determined arterial roads and the collector path to form concentric radial imaginary axes of Kendari City, namely:

1. A concentric system is formed from primary arterial roads that connect South Konawe District - Kendari City - North Konawe District, City Center - Nambo Beach - South Konawe District, South Konawe District - City Center via the western route. For the development of concentric patterns, it needs to be supported by the development of road networks, especially inner ring roads, especially in the western part of the City Center, which will form a framework for the movement system in the downtown area so that it is not concentrated on the main road lines.

2. The southern ring road, which will connect new centers in the eastern region, namely the port area, the Old City, the Industrial Center, and Terminal A to the Puuwatu Subdistrict. These roads will function as a radial system.

Along the primary arterial roads, green open space will be formed by island roads, median roads, pedestrian green lanes, parking lots, and community yards, with the $30 \mathrm{~m}$ corridor covering the left and right sides of the road. This spatial GOS will reinforce the concentric radial axes that makeup Kendari City and will visually make Kendari Bay and its surroundings the Kendari City focal point.

\subsection{Matrix}

The matrix will be developed as ecological points for the migration of animals or humans when the ecological path or corridor cannot be connected. In addition, the matrix will also be developed as ecological points in building-dense areas or in areas that are predicted to 
experience rapid development or at transportation points that allow human and motor vehicle accumulation. The matrix can be in the form of a green wall and green roof, backyard garden, neighborhood park, urban village park, subdistrict park, and city park. The matrix will function as follows.

1. Microclimate modifier in building-dense areas and traffic-intensive areas, such as in West Kendari Subdistrict, Mandonga Subdistrict, and Kadia Subdistrict as shown on urban surface temperature maps.

2. Control and barrier to air, noise, and visual pollutions as well as skyline urban areas.

3. As a shelter for pedestrians and public vehicle users at transport points

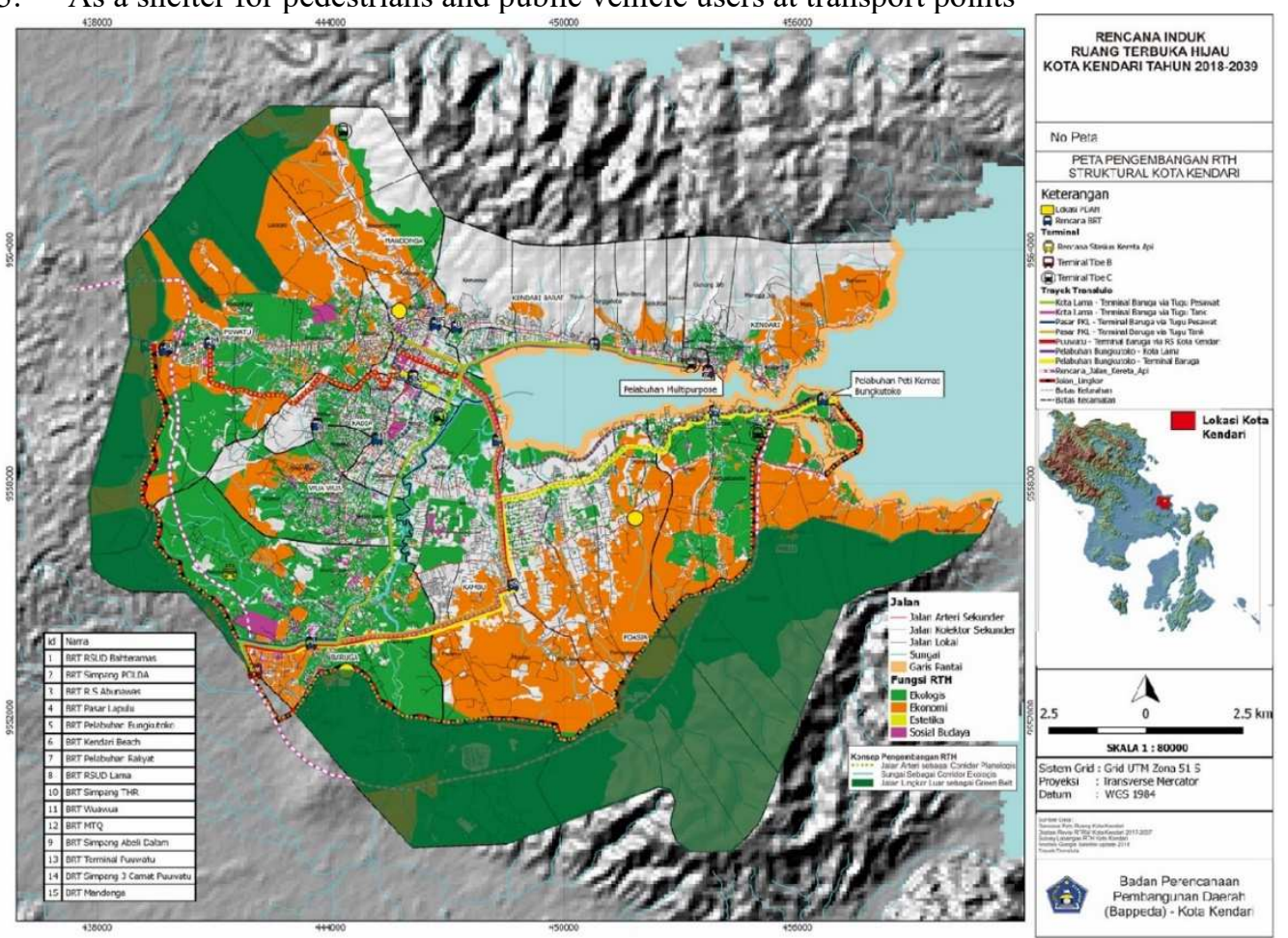

Figure 4. Implementation of structural GOS development concept. Source: RTRW of Kendari City 2017-3037 and Analysis, 2018

Development of existing GOS in Kendari City uses the basic development concept with structural green space modeling to have better synchronization and integration. There are 3 structural green space concepts in Kendari City related to the development of existing green open space, namely ecological path, corridor, and matrix. In the future, urban forest areas, wetlands, city parks, and green lands will function as part of the development of the ecological path concept.

Specifically, in the outer ring road area of Kendari City, from the side to the border areas of the city and regency, it will function as a green belt for the outermost areas of the city for ecological functions including water catchment areas, city lungs, and for cooling the surrounding area. Meanwhile, for the inner city area, the wetland area and the mangrove with linear distribution type will also function as a green belt in the Kendari Bay area, besides 
functioning for the prevention of interruptions and waves, it can also be ecologically beneficial as other fish and fauna habitats.

The concept of developing green open space through the corridor is for green open areas with a longitudinal structure and connected to ecological functions. The development is carried out on GOS in median and roadside which indirectly serves to connect between one green open space to another to form continuity. Median and roadside GOS in arterial road lanes in the city are an important priority in the development since they can cool the temperature of the area, provide shade, and absorb vehicle pollution.

The implementation of the matrix concept on GOS in Kendari City is carried out at the locations of green open spaces and could not be connected to the ecological and corridor paths. Thus, the distribution model of green open space is more likely to be dispersed. The development of matrix concepts is carried out in green open spaces such as yard parks, neighborhood parks, urban village parks, subdistrict parks, and city parks that are not connected to each other. The spread of green open space can function as a microclimate modifier in residential areas that are densely packed, air pollution barriers, and shelters at several transportation points.

\section{Conclusion}

The concept of synergy and synchronization of existing open space adopts the concept of structural green open space which consists of the concept of ecological path, corridor, and matrix. The concept of the ecological path is applied to production forest areas and mixed gardens that serve as a buffer for the ecology of the city as well as several areas that are designated as green belts such as mangrove areas with the aim of developing economic, environmental, and urban aesthetics. The corridor concept is used to connect spreading GOS into the development and optimization of GOS edges and the median of the road in the form of linear RTH. Their main functions are as a buffer zone on the road area and supporting the river border area. The matrix concept is applied to small-scale green open space at certain points that are spread over the home garden area, neighborhood parks, urban village parks, subdistrict parks, and city parks.

\section{References}

[1] Benedict, M.A.; McMahon, M. T. (2006) Green infrastructure: Linking landscape and communities. Island press, Washington.

[2] Bolt, D. (1983) Urban form and energy for transportation. PIVVS. Dhague.

[3] Carr, M. H.; Hoctor, T.D.; Goodison, C.; Zwick, P.D.; Green, J.; Hernandez, P.; et al. (2002) Final report: Southeastern ecological framework, http://www.geoplant.ufl.edu/epa/index.html-accessed 261009 .

[4] Dokumen Rencana Tata Ruang Wilayah (RTRW) Kota Kendari Tahun 2017-2037

[5] Hoctor. T.S.; Carr, M.H.; Zwick, V.D. (2000). Identified a linkage reserve system using a regional landscape approach: the Florida ecological network. Conserv. Biol. 144. 984-1000.

[6] Kota Kendari dalam Angka 2018, Badan Pusat Statistik Provinsi Sulawesi Tenggara

[7] Lewis, Jr.,P.H. (1964). Quality corridor for Wiscounsin. Landscape Architechture. 54. 100-107.

[8] Luas RTH Perkotaan Eksisting di Kota Kendari (2017). Dinas Lingkungan Hidup dan Kehutanan Kota Kendari.

[9] Noss, R.F., Harris, L. D. (1986). Nodes network and the MUMS preserving biodiversity at all scales. Environmental Management. 10. 299-309 
[10] Peraturan Menteri Nomor.05/PRT/M/2008 Tentang Pedoman Penyediaan dan Penataan Ruang Terbuka Hijau Perkotaan

[11] Peraturan Menteri PU-PR Nomor 5 Tahun 2008. Pedoman Penyediaan RTH Perkotaan.

[12] Pinho, O. S., \& Orgaz, M. D. (2000). The Urban Heat Island in A Small City in Coastal Portugal. Int J Biometeorol, 44 , 198- 203.

[13] Rencana Induk Ruang Terbuka Hijau Kota Kendari Tahun 2017-2037, (2018). Dinas Perencanaan dan Pembangunan Daerah (Bappeda) Kota Kendari.

[14] Schrijnen, Pieter M. (2002). Infrastructure networks and red green pattern in city regions. Landscape and urban planning. 48. 192-204.

[15] US.EPA (U.S. Environmental Protection Agency). 1998. Condition of the Mid-Atlantic Estuaries. EPA/600/R-98/147. Office of Research and Development, U.S. Environmental Protection Agency, Washington, DC, USA.

[16] Wickham, James D et al. (2010). A national assessment of green infrastructure and change for the conterminous united stated using morphological image processing. Landscape and urban planning. 94. 186-195. 